\title{
Characterization of commercially available products of aronia according to their metal content
}

\author{
Aleksandra N. Pavlovićc ${ }^{1, \star}$, Jelena M. Brcanović ${ }^{1}$, Jovana N. Veljković ${ }^{1}$, Snežana S. Mitić ${ }^{1}$, \\ Snežana B. Tošić ${ }^{1}$, Biljana M. Kaličanin ${ }^{2}$, Danijela A. Kostić1, Miodrag S. Đorđevićc ${ }^{1}$ \\ and Dragan S. Velimirović \\ 1 University of Niš, Faculty of Sciences and Mathematics, Department of Chemistry, Višegradska 33, P.O. Box 224, 18000 Niš, Serbia \\ 2 University of Niš, Faculty of Medicine, Department of Pharmacy, Blvd. Dr Zorana Đinđića 81, 18000 Niš, Serbia
}

Received 11 February 2015 - Accepted 4 September 2015

\begin{abstract}
Introduction. Among different fruit species, aronia have attracted a great attention because of its wide range of protective effects with potential benefits for human health. Furthermore, the consumption of products of aronia (juice, tea, berries) is becoming a part of a healthy lifestyle. Materials and Methods. The multi-element characterization of products of aronia has been carried out using inductively coupled plasma atomic emission spectrometry (ICP-AES). Results and Discussion. Among the major elements, the most abundant are K, Ca and P, followed by the $\mathrm{Mg}$ and $\mathrm{Na}$. Fe, $\mathrm{Zn}, \mathrm{Mn}, \mathrm{Cu}, \mathrm{Bi}$ and $\mathrm{Si}$ are the most abundant among the microelements. In terms of heavy metals (As, $\mathrm{Cd}, \mathrm{Pb}$ ), it can be concluded that the concentrations of them are below permissible levels (PLs) prescribed by national legislation in all samples. The chemometric techniques of principal component analysis (PCA) and cluster analysis (CA) were used to differentiation of products aronia according to their metal content. The application of PCA and CA was resulted in two clusters with similarities in the mineral composition. The first cluster includes tea bag samples (T1-T6). The second cluster includes berries (B1, B2), juices (J1-J4) and leaves (L). Conclusion. Data obtained in this study showed that analyzed products are potentially a rich source of some dietary metals such are $\mathrm{K}, \mathrm{Ca}, \mathrm{P}, \mathrm{Mg}, \mathrm{Na}$, $\mathrm{Fe}$ and $\mathrm{Zn}$. Obtained results could be also used as selection criteria for further use of products of aronia as a part of conventional diet.
\end{abstract}

Keywords: Serbia / chockeberry / Aronia melanocarpa / trace elements / heavy metals / ICP-AES / nutritive value

\begin{abstract}
Résumé - Caractérisation des produits commercialisés à base d'aronia noire (Aronia melanocarpa [Michx.]) en fonction de leur teneur en métal. Introduction. Parmi les différentes espèces de fruits, les Aronia ont attiré l'attention en raison de la vaste gamme d'effets protecteurs et des bénéfices potentiels pour la santé humaine. En outre, la consommation de produits d'aronia noire (jus, thé, fruits) est en train de devenir une composante d'un mode de vie sain. Matériels et méthodes. La caractérisation multi-critères des produits d'aronia noire a été effectuée en spectrométrie d'émission atomique par torche à plasma (ICP-AES). Résultats et discussion. Parmi les macro-éléments, les plus abondants sont $\mathrm{K}$, Ca et $\mathrm{P}$, suivis par $\mathrm{Mg}$ et $\mathrm{Na}$. Fe, $\mathrm{Zn}, \mathrm{Mn}, \mathrm{Cu}, \mathrm{Bi}$ et $\mathrm{Si}$ sont les plus abondants parmi les microéléments. En termes de métaux lourds ( $\mathrm{As}, \mathrm{Cd}, \mathrm{Pb}$ ), les concentrations détectées dans tous les échantillons ont toutes été en-dessous des niveaux admissibles (PLS) prescrits par la législation nationale. Les techniques chimio-métriques d'analyse en composantes principales (ACP) et d'analyse de clusters (CA) ont été utilisées pour la différenciation des produits à base d'aronia en fonction de leur teneur en métal. L'application de l'APC et de la CA a conduit à deux clusters comportant des similitudes dans la composition minérale. Le premier groupe comprend les échantillons de sachets de thé (T1-T6). Le deuxième groupe comprend les baies (B1, B2), les jus (J1-J4) et les feuilles (L). Conclusion. Les produits analysés au cours de cette étude constituent une source potentielle riche en certains métaux alimentaires tels que $\mathrm{K}, \mathrm{Ca}, \mathrm{P}, \mathrm{Mg}, \mathrm{Na}, \mathrm{Fe}$ et $\mathrm{Zn}$. Les résultats obtenus pourraient également être utilisés comme critères de sélection pour une utilisation ultérieure de produits à base d'aronia noire comme ingrédients alimentaires traditionnels.
\end{abstract}

Mots clés : Serbie / aronia noire / Aronia melanocarpa / éléments trace / métaux lourds / ICP-AES / valeur nutritionnelle

^ Corresponding author: aleksandra.pavlovic@pmf.edu.rs 


\section{Introduction}

Siberian blueberry or black chokeberry (Aronia melanocarpa [Michx.] Elliot genus Aronia, subfamily Maloideae, family Rosaceae) is a berry that looks like a blueberry. The homeland of the plant is North America, however, because of its resistance to low temperatures is named the Siberian blueberry. Black chokeberry well tolerates winter frosts down to $-47{ }^{\circ} \mathrm{C}$. It grows as a shrub, and can reach a height of about $2 \mathrm{~m}$. The edible and medicinal part of the plant is a fruit that is more sour than blueberry. North American Indians consumed aronia as dried fruit or by grinding and combining it with meat or sweet bread. The fresh fruit is most often used as a cure for stomach problems, and chokeberry tea leaves for healing wounds [1].

A. melanocarpa contain a very large complex of chemical compounds. Many researchers are examining the chemical nature and activity of natural antioxidants in this fruit. Their berries are one of the richest plant sources of phenolic phytochemicals, including procyanidins and anthocyanins. The total content of organic acids is relatively low compared to other berries. The principal ones identified as malic acid and citric acid [2]. Other phenolic acids, including chlorogenic and neochlorogenic acid are present in small amounts [3]. All of these compounds are responsible for the antioxidant properties of this fruit. It is therefore, a useful preventive against cancer and effectively cleanses the body of harmful substances, heavy metals and radioactive elements. Also, aronia contains vitamins such as C, A, E, B2, B6 and B9. In addition, chokeberry contains fructose and sorbitol [4-8]. Among the minerals the most abundant are calcium, potassium, iron, molybdenum, manganese, phosphorus and iodine. The mineral content of fresh berries was found to be $440 \mathrm{mg} 100 \mathrm{~g}^{-1}$ [9] and $580 \mathrm{mg}$ $100 \mathrm{~g}^{-1}$ [10]. The aronia juice showed relative high average amounts of potassium and zinc [5]. Contents of heavy metals in fruits of chokeberry may change depending on harvest site and vegetation period [11]. Consumption of food containing heavy metals during a short period of time can cause digestive problems like constipation, vomiting, weight loss, abdominal pain, behavior change, anemia, lethargy, as well as, high blood pressure, nerve disorders, memory and concentration problems [12-14].

Multi-element analysis can be a very valuable tool in the characterization of foodstuffs. Aronia is a rich source of minerals. Current scientific literature lacks the data on its mineral content. In addition to this, there is only one study about minerals content of this fruit [5]. Also, there is no available data on the element content in products of aronia. There are many different products of aronia widely consumed in our daily diet worldwide. Because of this, it is important to determine their nutrient composition as well as levels of potentially toxic elements so that their effect on human health can be understood. It is also important to try to elucidate whether or not there are any relationships between different products of aronia. Therefore, the first objective of this study was to determine the content of macro elements, as well as of micro-element in products of aronia in order to verify the quality of the composition in the same. For this purpose, the atomic emission spectrometry with inductively coupled plasma as an excitation source (ICP-AES)
Table I. Emission wavelength, limit of detection (LOD), limit of quantification (LOQ) and correlation coefficient of the calibration curves for each element determination.

\begin{tabular}{lcccc}
\hline Element & $\begin{array}{c}\lambda \\
(\mathrm{nm})\end{array}$ & $\begin{array}{c}\text { LOD } \\
\left(\mathrm{mg} \mathrm{kg}^{-1}\right)\end{array}$ & $\begin{array}{c}\text { LOQ } \\
\left(\mathrm{mg} \mathrm{kg}^{-1}\right)\end{array}$ & $\begin{array}{c}\text { Correlation } \\
\text { coefficient }\end{array}$ \\
\hline $\mathrm{Al}$ & 396.152 & 0.0425 & 0.1401 & 0.9995 \\
$\mathrm{As}$ & 189.042 & 0.0450 & 0.1512 & 0.9998 \\
$\mathrm{~B}$ & 249.773 & 0.0087 & 0.0287 & 0.9966 \\
$\mathrm{Ba}$ & 455.403 & 0.0012 & 0.0037 & 0.9999 \\
$\mathrm{Ca}$ & 422.673 & 0.0250 & 0.0837 & 1 \\
$\mathrm{Cd}$ & 226.502 & 0.0037 & 0.0125 & 0.9999 \\
$\mathrm{Co}$ & 228.616 & 0.0075 & 0.0250 & 0.9999 \\
$\mathrm{Cr}$ & 283.563 & 0.0150 & 0.0500 & 0.9997 \\
$\mathrm{Cu}$ & 324.754 & 0.0125 & 0.0437 & 1 \\
$\mathrm{Fe}$ & 259.94 & 0.0125 & 0.0400 & 0.9998 \\
$\mathrm{~K}$ & 766.49 & 0.1212 & 0.4025 & 0.9997 \\
$\mathrm{Li}$ & 670.784 & 0.0050 & 0.0150 & 0.9986 \\
$\mathrm{Mg}$ & 285.213 & 0.0050 & 0.0175 & 0.9999 \\
$\mathrm{Mn}$ & 257.61 & 0.0025 & 0.0075 & 0.9997 \\
$\mathrm{Mo}$ & 202.03 & 0.0125 & 0.0412 & 0.9999 \\
$\mathrm{Na}$ & 589.592 & 0.0375 & 0.1250 & 1 \\
$\mathrm{Ni}$ & 231.604 & 0.0100 & 0.0337 & 0.9998 \\
$\mathrm{P}$ & 213.618 & 0.0550 & 0.1850 & 0.9999 \\
$\mathrm{~Pb}$ & 220.353 & 0.0425 & 0.1429 & 1 \\
$\mathrm{Sb}$ & 231.147 & 0.0825 & 0.2762 & 0.9999 \\
$\mathrm{Se}$ & 196.09 & 0.0662 & 0.2187 & 1 \\
$\mathrm{Si}$ & 251.611 & 0.0237 & 0.0787 & 0.9989 \\
$\mathrm{Sn}$ & 189.989 & 0.0225 & 0.0750 & 0.9999 \\
$\mathrm{Sr}$ & 407.771 & 0.0005 & 0.0012 & 0.9998 \\
$\mathrm{~V}$ & 309.311 & 0.0087 & 0.0275 & 0.9999 \\
$\mathrm{Zn}$ & 213.856 & 0.0025 & 0.0075 & 0.9998 \\
\hline & & & &
\end{tabular}

was used. The second objective was to apply the chemometric techniques of principal component analysis (PCA) and cluster analysis (CA) to results obtained from the atomic spectrometric analysis to characterize and differentiate the studied products of aronia.

\section{Materials and methods}

\subsection{Instrumentation}

All analysis was carried out on iCAP 6000 inductively coupled plasma optical emission spectrometer (Thermo Scientific, Cambridge, UK) that uses an Echelle optical design and a change injection device solid-state detector. The operating conditions for the ICP-AES instrument were: flush pump rate $100 \mathrm{rpm}$, analysis pump rate $50 \mathrm{rpm}$, RF power $1150 \mathrm{~W}$, nebulizer gas flow rate $0.7 \mathrm{~L} \mathrm{~min}^{-1}$, coolant gas flow rate $12 \mathrm{~L} \mathrm{~min}^{-1}$, auxiliary gas flow rate $0.5 \mathrm{~L} \mathrm{~min}^{-1}$, dual (ax$\mathrm{ial} / \mathrm{radial}$ ) viewed plasma mode and sample uptake delay $30 \mathrm{~s}$.

The emission wavelength, the detection (LOD) and quantification (LOQ) limits and the correlation coefficients of the calibration curves for the elements studied are given in table $I$.

\subsection{Reagents}

Ultra-scientific (USA) ICP multi-element standard solutions of about $20.00 \pm 0.10 \mathrm{mg} \mathrm{L}^{-1}$ were used as a stock 
solution for calibration. The plastic containers used for storing the samples were cleaned to avoid contamination of the samples with traces of any metals. Containers were treated with $20 \%$ nitric acid and washed with ultra-pure water $0.05 \mu \mathrm{S} \mathrm{cm}^{-1}$ (MicroMed high purity water system, TKA Wasseraufbereitungssysteme $\mathrm{GmbH})$. Nitric acid (65\%), perchloric acid (Merck) and hydrogen peroxide (30\%) (Fluka, Buchs, Switzerland) are both of analytical grade.

\subsection{Samples}

Thirteen of commercially available aronia product samples, berries (B1, B2), leaves (L), juices (J1-J4) and filter bag teas (T1-T6), were purchased at local markets in Serbia.

\subsection{Sample preparation}

\subsubsection{Tea, berry and leaf samples}

Samples were mineralized according to a modification of the Kara method [15] as follows: an appropriate amount of aronia products $(2 \mathrm{~g})$ was weighed accurately and transferred in acid washed porcelain crucibles, heated gradually and maintained at $250{ }^{\circ} \mathrm{C}$ for $2 \mathrm{~h}$ and fired at $450{ }^{\circ} \mathrm{C}$ for $16 \mathrm{~h}$ in a muffle furnace. The ashes were then treated with $5 \mathrm{~mL}$ concentrate $\mathrm{HNO}_{3}$, evaporated to dryness on a steam bath and returned to the furnace at $450{ }^{\circ} \mathrm{C}$ for $1 \mathrm{~h}$. The resulting ash was than treated with $5 \mathrm{~mL}$ concentrate $\mathrm{HNO}_{3}$, filtered and transferred to a $25 \mathrm{~mL}$ volumetric flask. Solution had been rinsed with $0.5 \% \mathrm{HNO}_{3}$.

\subsubsection{Juice samples}

Five $\mathrm{mL}$ of aronia juice was poured with $40 \mathrm{~mL}$ of $65 \%$ nitric acid. The mixture was heated in a sand bath for one hour at $150{ }^{\circ} \mathrm{C}$. Then $1 \mathrm{~mL}$ of $70 \%$ perchloric acid was added and heated for another hour. When cool, $40 \mathrm{~mL}$ water was added and drained through quantitative filter paper (black and white stripe) in a $50 \mathrm{~mL}$ flask and filled up with deionized water to the mark.

\subsection{Validation}

The validation process of the measurements, based on ICP-OES technique, involved the linearity of the calibration curve, detection (LOD) and quantification limits (LOQ) ( $t a-$ ble I). Certified reference material supplied by The China National Analysis Center for Iron and Steel, Beijing, China (NCS ZC73036), was analysed in order to check the accuracy of the instrument. Samples were handled according to the supplier's specifications. Linearity was assessed by the correlation coefficients of calibration curves.

\subsection{Statistical analysis}

The multivariate analysis was applied for data association. Differences in the average metal concentrations observed between subsamples were tested by the Tukey's test. The principal components analysis (PCA) was performed to assess the correspondences among the different components (metals) of products of aronia. A cluster analysis (CA) was applied to the element concentrations and samples analyzed using Ward's method, with Euclidian distances as the criterion for forming clusters of samples. All statistical analyses involving the experimental data were performed using Statistica 8.0 (StartSoft, Tusla, Oklahoma, USA). A probability level of $P<0.05$ was considered statistically significant [16].

\section{Results and discussion}

After digestion, 26 elements were determined in thirteen samples of products of aronia using ICP-AES. The mean concentrations of elements, expressed as $\mathrm{mg} \mathrm{kg}^{-1}$, are shown in table II. All elements can be divided into following groups: 1) Macro-elements (K, $\mathrm{Ca}, \mathrm{P}, \mathrm{Mg}$ and $\mathrm{Na}), 2$ ) Essential trace elements ( $\mathrm{Zn}, \mathrm{Fe}, \mathrm{Se}, \mathrm{Cu}, \mathrm{Mo}, \mathrm{Cr}), 3$ ) Trace elements that are probably essential ( $\mathrm{Mn}, \mathrm{Si}, \mathrm{Ni}, \mathrm{B}, \mathrm{V})$ and 4) toxic elements $(\mathrm{Pb}, \mathrm{Cd}, \mathrm{Hg}, \mathrm{As})[17]$.

\subsection{Potassium as major macro-element}

$\mathrm{Ca}, \mathrm{P}, \mathrm{Mg}$ and $\mathrm{K}$ belong to the necessary macro-elements. They do not enter into the structure of the tissue, but are responsible for the control and regulation of metabolism and therefore, preserve the health of the organism. Minerals are the guardians of health without which the body cannot properly function. The major macro-element in the analyzed samples was $\mathrm{K}$ (table II) with average concentrations of $3,842 \mathrm{mg} \mathrm{kg}^{-1}$ in berries, 2,623 in leaves, 2,123 in juices and 1,477 in teas. The recommended daily intake of $\mathrm{K}$ range from $0.4 \mathrm{~g}$ for infants, $3.8 \mathrm{~g}$ for children aged 4-8 years and $4.7 \mathrm{~g}$ for adolescents, women and men [19]. Average Ca contents in the analyzed samples were $884 \mathrm{mg} \mathrm{kg}^{-1}$ in berries, 3,731 in leaves, 658 in juices and 807 in teas. The recommended daily $\mathrm{Ca}$ intake [18] for infants is $210 \mathrm{mg}$, for children aged 4-8 years is $800 \mathrm{mg}, 1,300 \mathrm{mg}$ for adolescents and for women and men, depending on the period, may vary from $1,000-1,200 \mathrm{mg}$.

Other major elements such as $\mathrm{P}, \mathrm{Mg}$ and $\mathrm{Na}$ were present in samples with average concentrations of $598 \mathrm{mg} \mathrm{kg}^{-1}$, $371 \mathrm{mg} \mathrm{kg}^{-1}$ and $14.6 \mathrm{mg} \mathrm{kg}^{-1}$ in berries, $1,514,827,18.2$ in leaves, 597, 353 and 38.7 in juices, 361, 197 and 21.2 in teas, respectively. The recommended daily intakes of $\mathrm{P}, \mathrm{Mg}$ and $\mathrm{Na}$ for infants are $100 \mathrm{mg}, 30 \mathrm{mg}$ and $0.12 \mathrm{mg}$, for children aged $4-8$ years 500,130 and 1.2, for adolescents are 1,250, 400 and 1.5 , for man and women 700,400 and 1.5 , respectively [19]. The content of macro-elements in the studied juice samples were higher compared to the values presented in literature for berry juices [20]. Also, compared to the other commercially available berry juices, investigated chokeberry juices could be considered as a good source of macro-elements. 
Table II. Macro- and micro-element contents* (in $\mathrm{mg} \mathrm{kg}^{-1}$ ) in product samples of aronia (B-berries, L-leaves, J-juices, T-teas). Values are the mean $\pm \mathrm{SD}(n=3)$. Values with different letters within columns are statistically different at $P<0.05$ by Tukey's test. ND $=$ not detected.

\begin{tabular}{lccccc}
\hline Samples** $^{* *}$ & $\mathrm{Na}$ & $\mathrm{K}$ & $\mathrm{Ca}$ & $\mathrm{Mg}$ & $\mathrm{P}$ \\
\hline B1 & $12.5 \pm 0.2^{\mathrm{b}}$ & $2,707 \pm 27^{\mathrm{fg}}$ & $601 \pm 12^{\mathrm{de}}$ & $164 \pm 1^{\mathrm{bc}}$ & $239 \pm 1^{\mathrm{b}}$ \\
B2 & $16.8 \pm 0.2^{\mathrm{c}}$ & $4,977 \pm 47^{\mathrm{i}}$ & $1,167 \pm 23^{\mathrm{g}}$ & $578 \pm 6^{\mathrm{i}}$ & $956 \pm 5^{\mathrm{j}}$ \\
L & $18.2 \pm 0.2^{\mathrm{cd}}$ & $2,623 \pm 26^{\mathrm{f}}$ & $3,731 \pm 30^{\mathrm{j}}$ & $827 \pm 18^{\mathrm{j}}$ & $1,514 \pm 10^{\mathrm{l}}$ \\
J1 & $28.5 \pm 0.4^{\mathrm{e}}$ & $848 \pm 6^{\mathrm{c}}$ & $1,225 \pm 23^{\mathrm{h}}$ & $589 \pm 9^{\mathrm{i}}$ & $1,037 \pm 7^{\mathrm{k}}$ \\
J2 & $50.4 \pm 2.9^{\mathrm{h}}$ & $2,777 \pm 128^{\mathrm{g}}$ & $571 \pm 29^{\mathrm{d}}$ & $251 \pm 10^{\mathrm{e}}$ & $615 \pm 8^{\mathrm{i}}$ \\
J3 & $56.3 \pm 0.8^{\mathrm{i}}$ & $1,664 \pm 36^{\mathrm{e}}$ & $698 \pm 14^{\mathrm{f}}$ & $363 \pm 7^{\mathrm{h}}$ & $568 \pm 8^{\mathrm{h}}$ \\
J4 & $19.6 \pm 0.3^{\mathrm{d}}$ & $3,204 \pm 23^{\mathrm{h}}$ & $138 \pm 1^{\mathrm{a}}$ & $209 \pm 2^{\mathrm{d}}$ & $167 \pm 1^{\mathrm{a}}$ \\
T1 & $18.6 \pm 0.1^{\mathrm{cd}}$ & $652 \pm 3^{\mathrm{b}}$ & $628 \pm 2^{\mathrm{e}}$ & $183 \pm 1^{\mathrm{c}}$ & $526 \pm 1^{\mathrm{g}}$ \\
T2 & $9.4 \pm 0.4^{\mathrm{a}}$ & $1,266 \pm 8^{\mathrm{d}}$ & $469 \pm 4^{\mathrm{b}}$ & $114 \pm 1^{\mathrm{a}}$ & $317 \pm 3^{\mathrm{d}}$ \\
T3 & $33.0 \pm 0.7^{\mathrm{f}}$ & $2,792 \pm 106^{\mathrm{g}}$ & $1,395 \pm 23^{\mathrm{i}}$ & $338 \pm 1^{\mathrm{g}}$ & $285 \pm 1^{\mathrm{c}}$ \\
T4 & $40.8 \pm 0.1^{\mathrm{g}}$ & $2,612 \pm 24^{\mathrm{f}}$ & $1,263 \pm 17^{\mathrm{h}}$ & $306 \pm 2^{\mathrm{f}}$ & $282 \pm 1^{\mathrm{c}}$ \\
T5 & $12.5 \pm 0.2^{\mathrm{b}}$ & $385 \pm 4^{\mathrm{a}}$ & $517 \pm 9^{\mathrm{bc}}$ & $99 \pm 1^{\mathrm{a}}$ & $361 \pm 3^{\mathrm{e}}$ \\
T6 & $12.6 \pm 0.1^{\mathrm{b}}$ & $1,157 \pm 13^{\mathrm{d}}$ & $568 \pm 1^{\mathrm{cd}}$ & $144 \pm 1^{\mathrm{b}}$ & $397 \pm 3^{\mathrm{f}}$ \\
\hline
\end{tabular}

\begin{tabular}{|c|c|c|c|c|c|}
\hline Samples & $\mathrm{Zn}$ & $\mathrm{Fe}$ & $\mathrm{Se}$ & $\mathrm{Cu}$ & Mo \\
\hline B1 & $8.40 \pm 0.02^{\mathrm{h}}$ & $9.4 \pm 0.1^{b}$ & $0.21 \pm 0.01^{\mathrm{b}}$ & $0.82 \pm 0.01^{b}$ & $0.021 \pm 0.001^{\mathrm{ba}}$ \\
\hline B2 & $4.09 \pm 0.02^{\mathrm{f}}$ & $14.2 \pm 0.1^{\mathrm{c}}$ & $0.28 \pm 0.01^{\mathrm{b}}$ & $2.11 \pm 0.01^{\mathrm{f}}$ & $0.016 \pm 0.001^{\mathrm{bb}}$ \\
\hline $\mathrm{L}$ & $11.64 \pm 0.04^{\mathrm{i}}$ & $21.5 \pm 0.1^{\mathrm{e}}$ & $0.51 \pm 0.03^{c}$ & $3.93 \pm 0.03^{\mathrm{i}}$ & $0.080 \pm 0.007^{\mathrm{ea}}$ \\
\hline $\mathrm{J} 1$ & $2.77 \pm 0.02^{\mathrm{c}}$ & $7.2 \pm 0.1^{\mathrm{a}}$ & $1.73 \pm 0.07^{\mathrm{f}}$ & $0.68 \pm 0.02^{\mathrm{a}}$ & ND \\
\hline $\mathrm{J} 2$ & $2.87 \pm 0.15^{\mathrm{c}}$ & $25.2 \pm 0.2^{\mathrm{g}}$ & $1.08 \pm 0.05^{\mathrm{e}}$ & $2.41 \pm 0.06^{\mathrm{h}}$ & $0.050 \pm 0.002^{\mathrm{ca}}$ \\
\hline $\mathrm{J} 3$ & $3.45 \pm 0.05^{\mathrm{e}}$ & $10.0 \pm 0.1^{\mathrm{b}}$ & $0.72 \pm 0.04^{\mathrm{d}}$ & $1.01 \pm 0.03^{\mathrm{c}}$ & $0.064 \pm 0.004^{\mathrm{da}}$ \\
\hline J4 & $0.89 \pm 0.01^{\mathrm{a}}$ & $16.5 \pm 0.2^{\mathrm{d}}$ & ND & $4.51 \pm 0.02^{\mathrm{j}}$ & ND \\
\hline $\mathrm{T} 1$ & $5.18 \pm 0.01^{\mathrm{g}}$ & $38.1 \pm 0.1^{\mathrm{j}}$ & $0.45 \pm 0.02^{\mathrm{c}}$ & $2.09 \pm 0.02^{f}$ & $0.082 \pm 0.008^{\mathrm{ea}}$ \\
\hline $\mathrm{T} 2$ & $8.27 \pm 0.05^{\mathrm{h}}$ & $58.1 \pm 0.3^{\mathrm{k}}$ & $0.26 \pm 0.01^{\mathrm{b}}$ & $4.00 \pm 0.05^{\mathrm{i}}$ & $0.099 \pm 0.002^{\mathrm{fa}}$ \\
\hline $\mathrm{T} 3$ & $4.00 \pm 0.04^{\mathrm{f}}$ & $30.0 \pm 0.4^{\mathrm{i}}$ & $0.56 \pm 0.03^{c}$ & $1.76 \pm 0.02^{\mathrm{d}}$ & $0.050 \pm 0.003^{\mathrm{ca}}$ \\
\hline $\mathrm{T} 4$ & $5.11 \pm 0.03^{\mathrm{g}}$ & $37.6 \pm 0.2^{\mathrm{j}}$ & $0.45 \pm 0.03^{c}$ & $2.26 \pm 0.01^{\mathrm{g}}$ & $0.290 \pm 0.001^{\text {ha }}$ \\
\hline T5 & $2.41 \pm 0.02^{\mathrm{b}}$ & $28.0 \pm 0.1^{\mathrm{h}}$ & $0.47 \pm 0.03^{c}$ & $1.99 \pm 0.02^{\mathrm{e}}$ & $0.129 \pm 0.007^{\mathrm{ga}}$ \\
\hline T6 & $3.07 \pm 0.02^{\mathrm{d}}$ & $22.8 \pm 0.1^{\mathrm{f}}$ & $0.45 \pm 0.03^{\mathrm{c}}$ & $2.39 \pm 0.01^{\mathrm{h}}$ & $0.130 \pm 0.001^{\mathrm{ga}}$ \\
\hline Samples & $\mathrm{Mn}$ & $\mathrm{Ni}$ & $\mathrm{V}$ & $\mathrm{Si}$ & $\mathrm{Cr}$ \\
\hline B1 & $5.49 \pm 0.05^{\mathrm{c}}$ & $0.143 \pm 0.002^{\mathrm{a}}$ & $0.40 \pm 0.01^{b c}$ & $2.37 \pm 0.02^{c}$ & $0.49 \pm 0.01^{\mathrm{abc}}$ \\
\hline B2 & $17.89 \pm 0.09^{\mathrm{g}}$ & $0.740 \pm 0.010^{\mathrm{h}}$ & $1.58 \pm 0.03^{\mathrm{j}}$ & $6.37 \pm 0.02^{\mathrm{i}}$ & $0.53 \pm 0.02^{\mathrm{bcd}}$ \\
\hline $\mathrm{L}$ & $6.44 \pm 0.04^{\mathrm{d}}$ & $0.140 \pm 0.010^{\mathrm{a}}$ & $2.38 \pm 0.02^{\mathrm{k}}$ & $6.19 \pm 0.05^{\mathrm{h}}$ & $0.48 \pm 0.02^{\mathrm{ab}}$ \\
\hline $\mathrm{J} 1$ & $4.01 \pm 0.01^{\mathrm{b}}$ & $0.130 \pm 0.010^{\mathrm{a}}$ & $1.43 \pm 0.02^{\mathrm{i}}$ & $3.30 \pm 0.10^{\mathrm{e}}$ & $0.55 \pm 0.04^{\mathrm{bcd}}$ \\
\hline $\mathrm{J} 2$ & $11.77 \pm 0.05^{\mathrm{f}}$ & $0.290 \pm 0.020^{\mathrm{d}}$ & $1.00 \pm 0.01^{\mathrm{g}}$ & ND & $0.56 \pm 0.02^{\mathrm{cd}}$ \\
\hline $\mathrm{J} 3$ & $6.90 \pm 0.07^{\mathrm{d}}$ & $0.372 \pm 0.004^{\mathrm{e}}$ & $1.10 \pm 0.02^{\mathrm{h}}$ & ND & $0.74 \pm 0.02^{\mathrm{e}}$ \\
\hline J4 & $2.98 \pm 0.03^{\mathrm{a}}$ & $0.860 \pm 0.010^{\mathrm{i}}$ & $0.47 \pm 0.01^{\mathrm{d}}$ & $7.40 \pm 0.03^{\mathrm{j}}$ & $0.57 \pm 0.03^{\mathrm{d}}$ \\
\hline $\mathrm{T} 1$ & $9.15 \pm 0.05^{\mathrm{e}}$ & $0.260 \pm 0.010^{c}$ & $0.57 \pm 0.01^{\mathrm{e}}$ & $5.63 \pm 0.01^{\mathrm{g}}$ & $0.74 \pm 0.01^{\mathrm{e}}$ \\
\hline $\mathrm{T} 2$ & $2.63 \pm 0.02^{\mathrm{a}}$ & $0.296 \pm 0.004^{\mathrm{d}}$ & $0.31 \pm 0.01^{\mathrm{a}}$ & $2.18 \pm 0.03^{b}$ & $0.50 \pm 0.04^{\mathrm{abcd}}$ \\
\hline $\mathrm{T} 3$ & $52.2 \pm 0.8^{\mathrm{i}}$ & $0.426 \pm 0.003^{\mathrm{f}}$ & $0.96 \pm 0.02^{\mathrm{g}}$ & $5.71 \pm 0.03^{\mathrm{g}}$ & $0.56 \pm 0.02^{\mathrm{cd}}$ \\
\hline $\mathrm{T} 4$ & $29.7 \pm 0.1^{\mathrm{h}}$ & $0.568 \pm 0.002^{\mathrm{g}}$ & $0.91 \pm 0.02^{\mathrm{f}}$ & $6.30 \pm 0.09^{h i}$ & $0.85 \pm 0.02^{\mathrm{f}}$ \\
\hline $\mathrm{T} 5$ & $5.38 \pm 0.05^{\mathrm{c}}$ & $0.204 \pm 0.002^{\mathrm{b}}$ & $0.37 \pm 0.01^{\mathrm{b}}$ & $4.01 \pm 0.04^{\mathrm{f}}$ & $0.48 \pm 0.01^{\mathrm{ab}}$ \\
\hline T6 & $5.59 \pm 0.03^{c}$ & $0.400 \pm 0.010^{\mathrm{e}}$ & $0.42 \pm 0.02^{\mathrm{cd}}$ & $2.60 \pm 0.02^{\mathrm{d}}$ & $0.44 \pm 0.01^{\mathrm{a}}$ \\
\hline
\end{tabular}


Table II. Continued.

\begin{tabular}{|c|c|c|c|c|c|c|c|c|}
\hline Samples & \multicolumn{2}{|l|}{$\mathrm{Li}$} & \multicolumn{2}{|c|}{$\mathrm{Sr}$} & \multicolumn{2}{|c|}{$\mathrm{Al}$} & $\mathrm{Sn}$ & As \\
\hline B1 & \multicolumn{2}{|l|}{ ND } & \multicolumn{2}{|c|}{$1.57 \pm 0.01^{\mathrm{e}}$} & \multicolumn{2}{|c|}{$2.88 \pm 0.04^{\mathrm{b}}$} & $0.62 \pm 0.04^{\mathrm{ab}}$ & $0.36 \pm 0.03^{b c}$ \\
\hline B2 & \multicolumn{2}{|c|}{$6.75 \pm 0.02^{\mathrm{b}}$} & \multicolumn{2}{|c|}{$7.05 \pm 0.03^{\mathrm{i}}$} & \multicolumn{2}{|c|}{$4.40 \pm 0.20^{c}$} & $0.72 \pm 0.01^{\mathrm{c}}$ & $0.20 \pm 0.01^{\mathrm{a}}$ \\
\hline $\mathrm{L}$ & \multicolumn{2}{|c|}{$0.054 \pm 0.001^{\mathrm{a}}$} & \multicolumn{2}{|c|}{$8.30 \pm 0.06^{\mathrm{j}}$} & \multicolumn{2}{|c|}{$11.30 \pm 0.10^{f}$} & $0.61 \pm 0.01^{\mathrm{a}}$ & $0.33 \pm 0.01^{b}$ \\
\hline $\mathrm{J} 1$ & \multicolumn{2}{|l|}{ ND } & \multicolumn{2}{|c|}{$3.67 \pm 0.04^{\mathrm{g}}$} & \multicolumn{2}{|c|}{$1.64 \pm 0.06^{\mathrm{a}}$} & $1.05 \pm 0.03^{\mathrm{e}}$ & $0.79 \pm 0.03^{\mathrm{f}}$ \\
\hline $\mathrm{J} 2$ & \multicolumn{2}{|c|}{$0.044 \pm 0.002^{\mathrm{a}}$} & \multicolumn{2}{|c|}{$0.61 \pm 0.02^{\mathrm{b}}$} & \multicolumn{2}{|c|}{$7.30 \pm 0.30^{\mathrm{d}}$} & $1.05 \pm 0.04^{\mathrm{e}}$ & $0.55 \pm 0.01^{\mathrm{d}}$ \\
\hline $\mathrm{J} 3$ & \multicolumn{2}{|c|}{$0.072 \pm 0.002^{\mathrm{a}}$} & \multicolumn{2}{|c|}{$1.43 \pm 0.02^{\mathrm{d}}$} & \multicolumn{2}{|c|}{$9.70 \pm 0.70^{\mathrm{e}}$} & $1.09 \pm 0.02^{\mathrm{e}}$ & $0.73 \pm 0.02^{\mathrm{e}}$ \\
\hline $\mathrm{J} 4$ & \multicolumn{2}{|c|}{$0.016 \pm 0.001^{\mathrm{a}}$} & \multicolumn{2}{|c|}{$0.34 \pm 0.01^{\mathrm{a}}$} & \multicolumn{2}{|c|}{$5.10 \pm 0.30^{c}$} & $0.86 \pm 0.04^{\mathrm{d}}$ & $0.37 \pm 0.02^{\mathrm{bc}}$ \\
\hline $\mathrm{T} 1$ & $0.075 \pm 0.0$ & & $3.93 \pm$ & $0.01^{\mathrm{h}}$ & 16.20 & $\pm 0.05^{\mathrm{g}}$ & $0.58 \pm 0.01^{\mathrm{a}}$ & $0.30 \pm 0.02^{b}$ \\
\hline $\mathrm{T} 2$ & ND & & $1.01 \pm$ & $0.01^{\mathrm{c}}$ & 3.60 & $\pm 0.03^{\mathrm{b}}$ & $0.87 \pm 0.01^{\mathrm{d}}$ & $0.31 \pm 0.02^{\mathrm{b}}$ \\
\hline $\mathrm{T} 3$ & $0.064 \pm 0.0$ & & $8.40 \pm$ & $0.10^{\mathrm{k}}$ & 17.90 & $\pm 0.30^{\mathrm{h}}$ & $0.86 \pm 0.04^{\mathrm{d}}$ & $0.43 \pm 0.03^{\mathrm{c}}$ \\
\hline $\mathrm{T} 4$ & $0.055 \pm 0.0$ & & $9.10=$ & $0.02^{1}$ & 25.47 & $\pm 0.02^{\mathrm{i}}$ & $0.89 \pm 0.02^{\mathrm{d}}$ & $0.30 \pm 0.02^{\mathrm{b}}$ \\
\hline T5 & ND & & $3.69 \pm$ & $0.02^{\mathrm{g}}$ & 16.40 & $\pm 0.10^{\mathrm{g}}$ & $0.70 \pm 0.01^{\mathrm{bc}}$ & $0.98 \pm 0.03^{\mathrm{g}}$ \\
\hline T6 & ND & & $2.33=$ & $0.01^{\mathrm{f}}$ & 7.11 & $\pm 0.04^{\mathrm{d}}$ & $0.87 \pm 0.02^{\mathrm{d}}$ & $0.33 \pm 0.03^{\mathrm{b}}$ \\
\hline Samples & $\mathrm{Cd}$ & & $\mathrm{a}$ & & & $\mathrm{Sb}$ & $\mathrm{Co}$ & $\mathrm{B}$ \\
\hline B1 & $0.016 \pm 0.001^{\mathrm{a}}$ & & $0.01^{\mathrm{b}}$ & 0.091 & $.004^{\mathrm{e}}$ & ND & $0.043 \pm 0.002^{\mathrm{cd}}$ & $2.88 \pm 0.02^{\mathrm{de}}$ \\
\hline B2 & $0.041 \pm 0.001^{b}$ & & $0.04^{\mathrm{h}}$ & 0.048 & $0.000^{\mathrm{a}}$ & $0.29 \pm 0.01^{\mathrm{cdb}}$ & $0.019 \pm 0.001^{b}$ & $14.22 \pm 0.09^{j}$ \\
\hline $\mathrm{L}$ & $0.018 \pm 0.001^{\mathrm{a}}$ & & $\pm 0.10^{j}$ & 0.052 & $.002^{\mathrm{b}}$ & $0.24 \pm 0.02^{\mathrm{bca}}$ & ND & $5.22 \pm 0.03^{\mathrm{h}}$ \\
\hline $\mathrm{J} 1$ & $0.064 \pm 0.004^{\mathrm{h}}$ & & $0.03^{\mathrm{d}}$ & 0.061 & $.003^{\mathrm{b}}$ & ND & ND & $1.44 \pm 0.01^{\mathrm{b}}$ \\
\hline $\mathrm{J} 2$ & $0.053 \pm 0.004^{\mathrm{fg}}$ & & $=0.07^{\mathrm{c}}$ & 0.072 & $.004^{\mathrm{c}}$ & ND & $0.092 \pm 0.006^{\mathrm{g}}$ & ND \\
\hline $\mathrm{J} 3$ & $0.052 \pm 0.002^{\mathrm{efg}}$ & & $0.04^{\mathrm{d}}$ & 0.143 & $.006^{\mathrm{f}}$ & $0.54 \pm 0.02^{\mathrm{ea}}$ & $0.061 \pm 0.004^{\mathrm{ef}}$ & ND \\
\hline J4 & $0.050 \pm 0.002^{\mathrm{def}}$ & & $0.01^{\mathrm{a}}$ & & & $0.13 \pm 0.01^{\mathrm{ba}}$ & $0.010 \pm 0.001^{\mathrm{ab}}$ & $9.32 \pm 0.04^{\mathrm{i}}$ \\
\hline $\mathrm{T} 1$ & $0.047 \pm 0.002^{\mathrm{bcd}}$ & & $0.02^{\mathrm{g}}$ & 0.077 & $.003^{\mathrm{cd}}$ & $0.31 \pm 0.08^{\mathrm{cda}}$ & ND & $2.79 \pm 0.04^{\mathrm{d}}$ \\
\hline $\mathrm{T} 2$ & $0.035 \pm 0.002^{\mathrm{b}}$ & & $0.01^{\mathrm{b}}$ & 0.083 & $.003^{\mathrm{de}}$ & $0.66 \pm 0.02^{\mathrm{fa}}$ & $0.052 \pm 0.005^{\mathrm{de}}$ & $2.89 \pm 0.02^{\mathrm{de}}$ \\
\hline $\mathrm{T} 3$ & $0.036 \pm 0.003^{\mathrm{b}}$ & & $=0.10^{\mathrm{i}}$ & 0.205 & $0.006^{\mathrm{g}}$ & $0.16 \pm 0.07^{\mathrm{ba}}$ & $0.064 \pm 0.006^{\mathrm{f}}$ & $4.96 \pm 0.03^{\mathrm{g}}$ \\
\hline $\mathrm{T} 4$ & $0.037 \pm 0.003^{\mathrm{bc}}$ & & $=0.04^{\mathrm{i}}$ & 0.072 & $.001^{\mathrm{c}}$ & $0.37 \pm 0.08^{\mathrm{da}}$ & $0.144 \pm 0.002^{\mathrm{i}}$ & $3.38 \pm 0.04^{\mathrm{f}}$ \\
\hline T5 & $0.044 \pm 0.002^{\text {cde }}$ & & $0.01^{\mathrm{e}}$ & 0.085 & $.003^{\mathrm{de}}$ & $0.32 \pm 0.02^{\text {cda }}$ & $0.034 \pm 0.001^{\mathrm{c}}$ & $2.60 \pm 0.02^{\mathrm{c}}$ \\
\hline T6 & $0.059 \pm 0.001^{\mathrm{gh}}$ & 2.5 & $=0.01^{\mathrm{f}}$ & 0.053 & $0.002^{\mathrm{b}}$ & ND & $0.111 \pm 0.005^{\mathrm{h}}$ & $2.98 \pm 0.01^{\mathrm{e}}$ \\
\hline
\end{tabular}

\subsection{Presence of numerous micro-elements besides iron}

Micro-elements play important biological roles as an integral part of enzymes or proteine strucutres. Metallo-proteins are involved in electron transport, oxygen storage, redox processes, and metal transport. Also, some of trace elements have an important role in biochemical processes.

The major micro-element found in the analyzed samples was $\mathrm{Fe}$ (table II) with mean concentration of $11.8 \mathrm{mg} \mathrm{kg}$ in berries, $21.8 \mathrm{mg} \mathrm{kg}^{-1}$ in leaves, $14.7 \mathrm{mg} \mathrm{kg}^{-1}$ in juices and $35.8 \mathrm{mg} \mathrm{kg}^{-1}$ in bagged teas, followed by $\mathrm{Mn}(11.7,6.44,6.42$, $17.4 \mathrm{mg} \mathrm{kg}{ }^{-1}$, resp.), Zn (6.25, 11.64, 2.50, $4.67 \mathrm{mg} \mathrm{kg}^{-1}$, resp.), $\mathrm{Cu}\left(1.47,3.93,2.15,2.42 \mathrm{mg} \mathrm{kg}^{-1}\right.$, resp.) and $\mathrm{Se}$ $\left(0.25,0.51,0.88,0.44 \mathrm{mg} \mathrm{kg}^{-1}\right.$, resp.). Ozcan and Haciseferogullari [21] found $\mathrm{Fe}, \mathrm{Cu}$ and $\mathrm{Zn}$ contents of strawberry fruit of $12.15,1.65$ and $8.09 \mathrm{mg} \mathrm{kg}^{-1}$, respectively. In other study, Radwan and Salama [22] found $\mathrm{Cu}$ and $\mathrm{Zn}$ of 2.17 and $7.49 \mathrm{mg} \mathrm{kg}^{-1}$ in strawberry. According to Bagdatlioglu and Nergiz, [23] concentration ranges of $\mathrm{Fe}, \mathrm{Cu}$ and $\mathrm{Zn}$ in strawberry were $2.20-8.95,0.28-1.13$ and $0.80-1.67$, respectively and in cherry $1.73-5.92,0.84-0.90$ and $0.97-1.66 \mathrm{mg} \mathrm{kg}^{-1}$, respectively.
The content of toxic metals is one of the parameters which is necessary to assess in order to examine food safety. $\mathrm{Cd}$, $\mathrm{Pb}, \mathrm{Hg}, \mathrm{As}$ and $\mathrm{Sb}$ are physiologically useless, unnecessary and toxic [24]. For this group of elements the expression "heavy metals" is often used although it also comprises essential heavy metals such as $\mathrm{Fe}, \mathrm{Cu}, \mathrm{Zn}, \mathrm{Co}, \mathrm{Mn}$ and Mo, whose deficiency or excess in the diet may lead to adverse health effects. Heavy metals as pollutants in the working and living environment are a serious health and ecological problem because they are toxic, not biodegradable and have a long half-life in soil $[25,26]$. Concentrations of $\mathrm{As}, \mathrm{Pb}, \mathrm{Sb}$ and $\mathrm{Cd}$ in all analyzed samples were in the range of $0.20-0.98$, ND-0.205, ND-0.66 and $0.016-0.064 \mathrm{mg} \mathrm{kg}^{-1}$, respectively. The regulation of the content of toxic metals in most foods is regulated by the European Union Directive [27].

Concentrations of $\mathrm{As}$ and $\mathrm{Cd}$ in all analyzed samples were measured below the maximum permissible limits in foods; which are $1 \mathrm{mg} \mathrm{kg}^{-1}$ and $0.3 \mathrm{mg} \mathrm{kg}^{-1}$ for As and Cd, respectively [27,28]. The maximum $\mathrm{Pb}$ level permitted for fruit and small fruit are 0.10 and $0.20 \mathrm{mg} \mathrm{kg}^{-1}$, respectively [27]. The concentration of $\mathrm{As}, \mathrm{Cd}$ and $\mathrm{Pb}$ in the analyzed samples was below the maximum permissible limit. The accuracy of the developed procedure for metal determination was verified 
Table III. Correlation matrix of elements (Pearson correlation). ND = not detected.

\begin{tabular}{|c|c|c|c|c|c|c|c|c|c|c|c|c|c|}
\hline & $\mathrm{Na}$ & $\mathrm{K}$ & $\mathrm{Ca}$ & $\mathrm{Mg}$ & $\mathrm{P}$ & $\mathrm{Zn}$ & $\mathrm{Fe}$ & $\mathrm{Se}$ & $\mathrm{Cu}$ & Mo & $\mathrm{Cr}$ & $\mathrm{Mn}$ & $\mathrm{Ni}$ \\
\hline $\mathrm{K}$ & 0.116 & 1 & & & & & & & & & & & \\
\hline $\mathrm{Ca}$ & -0.003 & 0.609 & 1 & & & & & & & & & & \\
\hline $\mathrm{Mg}$ & 0.159 & 0.387 & 0.843 & 1 & & & & & & & & & \\
\hline $\mathrm{Zn}$ & -0.308 & 0.068 & 0.648 & 0.347 & 0.398 & 1 & & & & & & & \\
\hline $\mathrm{Fe}$ & -0.206 & -0.284 & -0.414 & -0.414 & -0.321 & 0.260 & 1 & & & & & & \\
\hline Mo & 0.119 & -0.239 & 0.082 & -0.225 & -0.242 & 0.123 & 0.537 & -0.166 & 0.088 & 1 & & & \\
\hline $\mathrm{Cr}$ & 0.415 & -0.023 & -0.096 & -0.034 & -0.189 & -0.156 & 0.153 & 0.057 & -0.198 & 0.471 & 1 & & \\
\hline $\mathrm{Mn}$ & 0.327 & 0.361 & 0.187 & 0.101 & -0.188 & -0.079 & 0.176 & -0.024 & -0.183 & 0.240 & 0.298 & 1 & \\
\hline $\mathrm{Ni}$ & 0.072 & 0.625 & -0.280 & -0.064 & -0.308 & -0.470 & -0.032 & -0.483 & 0.381 & 0.018 & 0.242 & 0.260 & 1 \\
\hline $\mathrm{V}$ & 0.251 & 0.392 & 0.865 & 0.980 & 0.913 & 0.363 & -0.360 & 0.367 & 0.014 & -0.159 & -0.002 & 0.129 & -0.097 \\
\hline $\mathrm{Al}$ & 0.279 & -0.135 & 0.200 & -0.091 & -0.203 & -0.011 & 0.399 & -0.138 & -0.027 & 0.752 & 0.602 & 0.602 & 0.061 \\
\hline $\mathrm{Sn}$ & 0.411 & -0.075 & -0.289 & -0.017 & -0.106 & -0.525 & -0.146 & 0.581 & -0.193 & -0.024 & 0.221 & 0.060 & 0.133 \\
\hline As & 0.286 & -0.546 & -0.173 & -0.082 & 0.016 & -0.424 & -0.292 & 0.559 & -0.432 & -0.095 & -0.065 & -0.207 & -0.417 \\
\hline $\mathrm{Cd}$ & 0.317 & -0.340 & -0.486 & -0.169 & -0.082 & -0.823 & -0.161 & 0.522 & -0.188 & -0.099 & 0.142 & -0.168 & 0.194 \\
\hline $\mathrm{Ba}$ & 0.093 & 0.385 & 0.470 & 0.478 & 0.378 & 0.398 & 0.139 & -0.089 & 0.103 & 0.410 & 0.194 & 0.689 & 0.103 \\
\hline $\mathrm{Pb}$ & 0.392 & -0.127 & 0.035 & -0.087 & -0.266 & 0.053 & 0.119 & 0.146 & -0.490 & 0.045 & 0.177 & 0.453 & -0.279 \\
\hline $\mathrm{Sb}$ & 0.052 & -0.142 & -0.011 & -0.084 & -0.081 & 0.247 & 0.465 & -0.316 & 0.250 & 0.358 & 0.380 & -0.020 & 0.100 \\
\hline Co & 0.412 & 0.031 & -0.218 & -0.378 & -0.463 & -0.15 & 0.277 & -0.040 & -0.105 & 0.700 & 0.295 & 0.376 & 0.159 \\
\hline B & -0.404 & 0.734 & 0.134 & 0.309 & 0.147 & -0.040 & -0.142 & -0.510 & 0.366 & -0.257 & -0.187 & 0.170 & 0.713 \\
\hline
\end{tabular}

using certified values. The agreement between experimental and certified values was good. The recovery values were in the range of $89-106 \%$, which indicates that the whole procedure could be considered suitable for metal determinations in analyzed samples.

Since the analyzed products of aronia have been widely consumed in daily diet worldwide, it is important to evaluate whether or not there is a relationship among the element contents in different products of aronia. Correlation analysis of total element contents in samples of aronia products showed moderate to strong correlations in seven groups of elements (table III): Group 1 - Ca, K, Mg, P, Zn, V; Group 2 - Fe, Cu, Mo; Group 3 - Cr, Al; Group 4 - Mn, Sr, Ba, Al; Group 5 Si, Sr, Ba; Group 6 - Li, Ni, B; Group 7 - As, Cd, Sn. Accordingly, relationships between each element are complex and rather difficult to explain individually.

\subsection{Chemometric techniques for correlation analyses}

Further elucidation may be obtained using more powerful chemometric techniques such as principal component analysis (PCA) and cluster analysis (CA). In particular, PCA is a very powerful data reduction technique that aims to identify a small number of factors that explain most of the variance observed in a much larger number of variables [29]. Through PCA, when the 25 variables (element contents) were used to classify samples of aronia products, a new data matrix accounting for $42.63 \%$ of the total variance was generated, where PC1 explained $24.92 \%$ of the variance in the data set and PC2 explained $17.71 \%$. All the elements were consequently well represented by these two principal components. $\mathrm{Ba}, \mathrm{Ca}, \mathrm{Sr}, \mathrm{Mg}$, $\mathrm{V}, \mathrm{Si}, \mathrm{B}, \mathrm{K}, \mathrm{Cd}, \mathrm{P}, \mathrm{Li}, \mathrm{Zn}$ and $\mathrm{Sn}$ displayed high values in the first component (PC1), while factor loadings for Mn (0.336), As (0.333), Se (0.329), Cu (0.288), Co (0.278), Ni (0.216) Pb (0.215), $\mathrm{Na}(0.202)$ and $\mathrm{Al}(0.176)$, were not as higher as the loadings of the other elements of the group. This may therefore imply a quasi-independent behavior within the group. The second component (PC2) was dominated by $\mathrm{Mo}, \mathrm{Fe}, \mathrm{Sb}$ and $\mathrm{Cr}$.

Behavior of variables on the PC1 and PC2 is shown in figure 1. A positive score means that the concentration of variables increases along the PC axes; a negative score means that the concentration of variables decreases along the axis and a score near 0 means that the concentration is poorly related to the PC axis. The direction of the variable arrows indicates the direction in which the concentration of the corresponding species increases most, and the length of the arrows equals the rate of change in that direction. The first component saturated $\mathrm{Ca}, \mathrm{Si}, \mathrm{Mg}, \mathrm{V}, \mathrm{B}, \mathrm{P}, \mathrm{Li}, \mathrm{K}, \mathrm{Si}, \mathrm{Zn}, \mathrm{Ni}, \mathrm{Cu}, \mathrm{Sr}, \mathrm{Ba}$ (negatively correlated with the component) and $\mathrm{Cd}, \mathrm{Sn}, \mathrm{Se}, \mathrm{As}$ (positively correlated with component). The second component saturated $\mathrm{Al}, \mathrm{Mo}, \mathrm{Co}, \mathrm{Mn}, \mathrm{Cr}, \mathrm{Pb}, \mathrm{Na}, \mathrm{Fe}, \mathrm{Sb}$ (positively correlated with the second component). 
Table III. Continued.

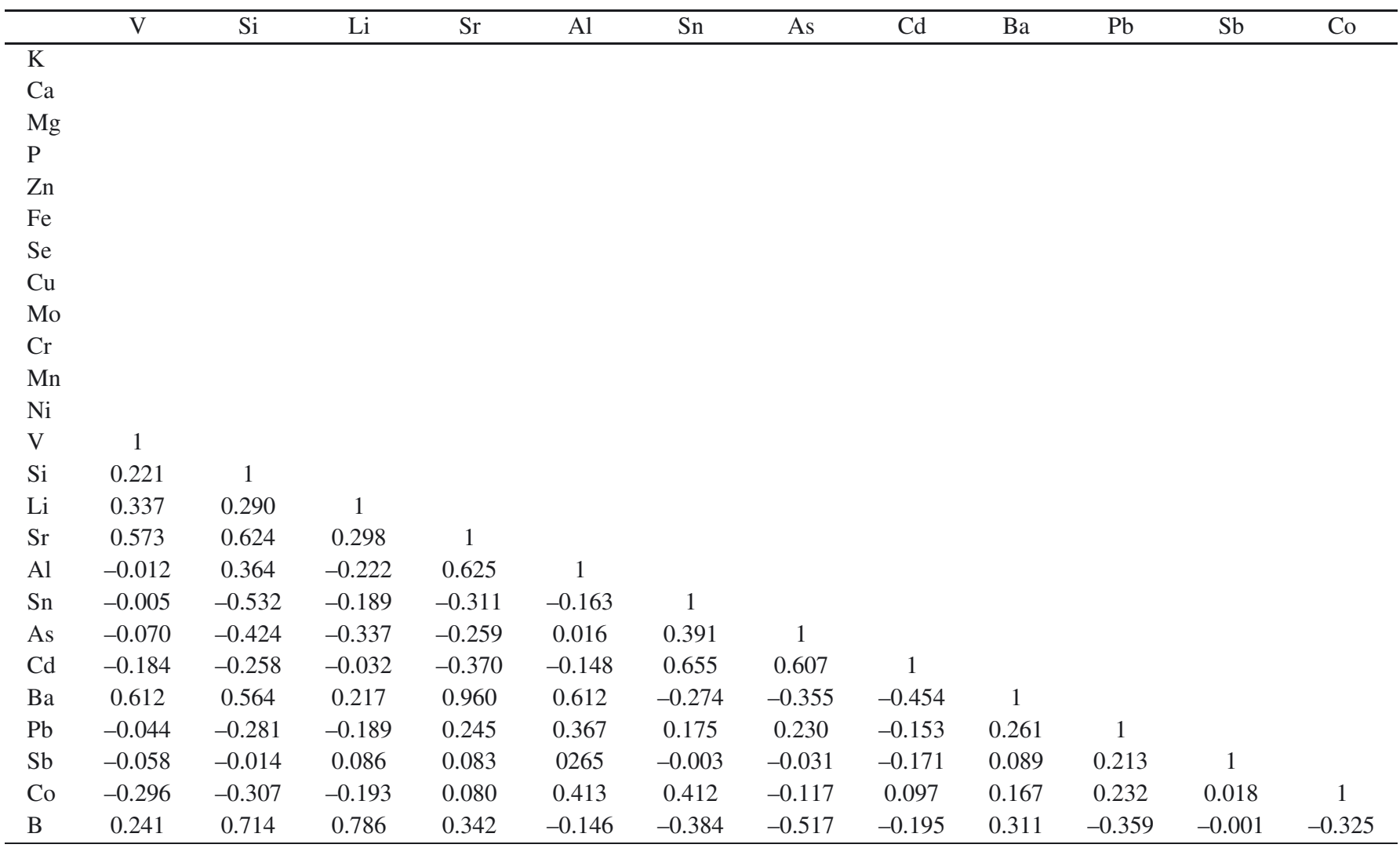

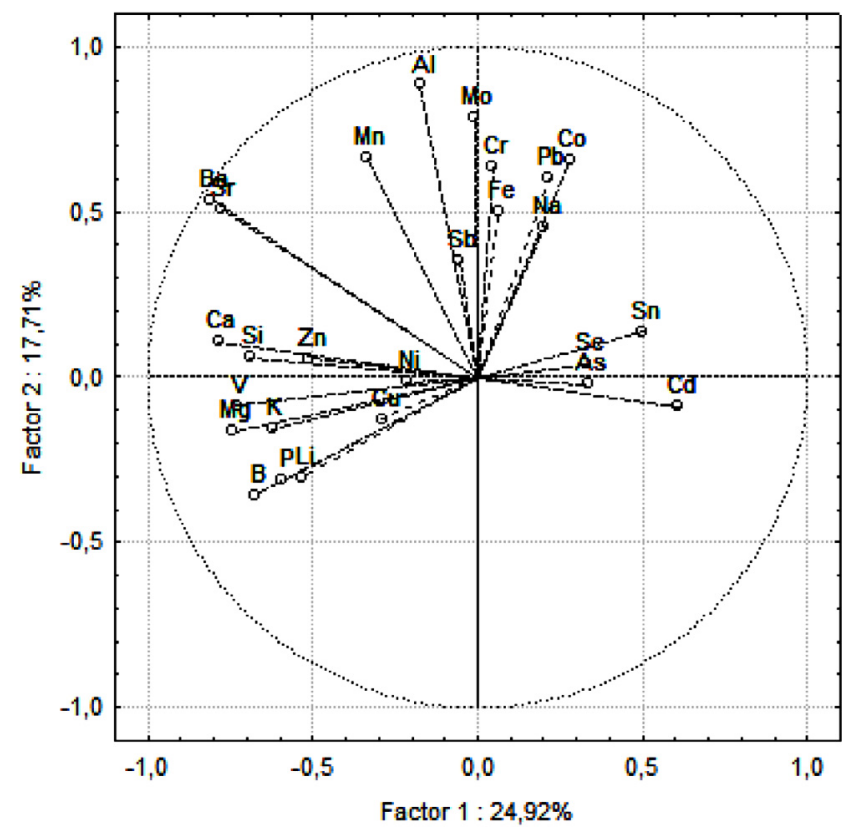

Figure 1. Principal component analysis of element contents in aronia products.

The layout of samples is in two-dimensional space given in figure 2. Tea bag samples (T1, T2, T5 and T6) are located close to each other in the region where they are the positive values

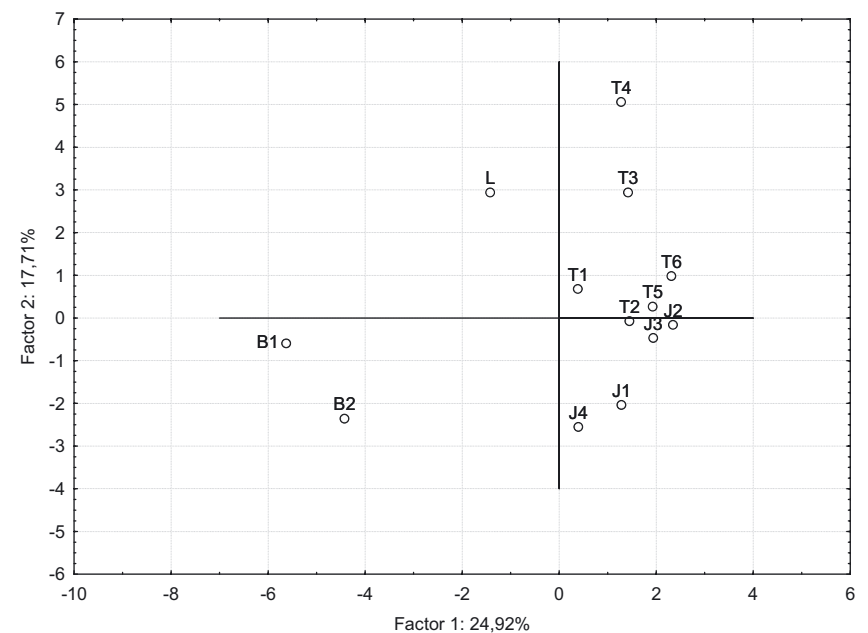

Figure 2. Principal component analysis (PCA) scores plot for the first PC (B-berries, L-leaves, J-juices, T-teas).

of the first component and the near-zero values of the second component. Tea bag samples T4 and T4 are also in this group. Juice samples (J1-J4) are grouped in the positive side of PC1 and negative side of PC2. Leaves (L) and berries are grouped in the negative side of $\mathrm{PC} 1$ and $\mathrm{PC} 2$. This clearly indicates that three classes are fully separated from PCA.

A cluster analysis was also applied to the element concentrations and analyzed samples. The Euclidian distance was 


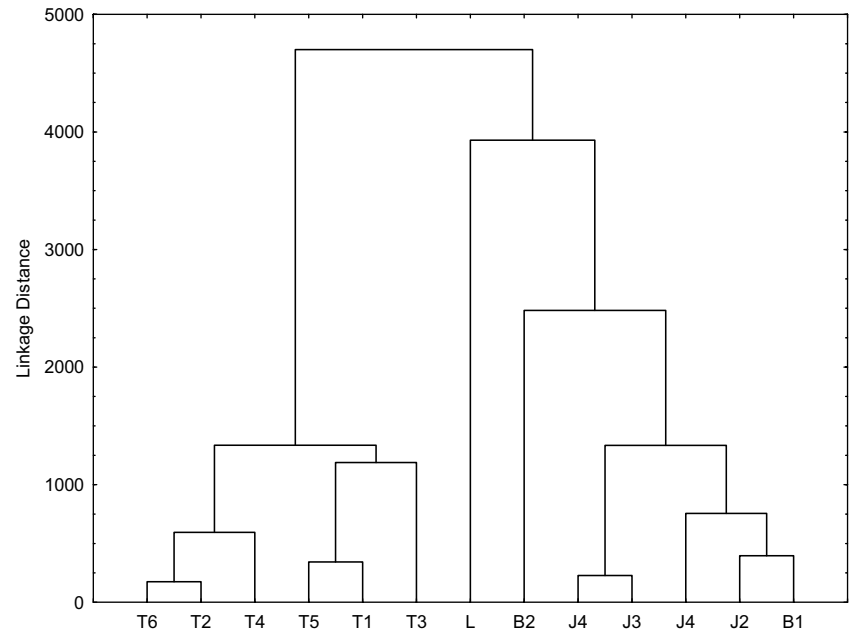

Figure 3. Dendogram of cluster analysis (Ward's method) of aronia product samples (B-berries, L-leaves, J-juices, T-teas).

used for similarity measurement and the Ward's method as amalgamation rule. Two well-separated clusters appeared in the corresponding dendogram (figure 3). The first cluster consisted of tea bag samples (T1-T6), and the second included berries (B1, B2), juices (J1-J4) and leaves (L).

\section{Conclusion}

Results obtained in this study enable us to gain some knowledge about element contents in commercially available products of aronia, as a part of the diet in disease prevention and health promotion. The analyzed products are a potentially rich source of some dietary metals such are $\mathrm{K}, \mathrm{Ca}, \mathrm{P}, \mathrm{Mg}$, $\mathrm{Na}, \mathrm{Fe}$ and $\mathrm{Zn}$. A widespread consumption of aronia and their products available in the world may be a major source of dietary essential elements for many people. With respect to toxic metals in dietary and safety standards, all our analyzed samples were found to be safe for human consumption.

Chemometric approach was used in order to determine the relationship among the element contents in aronia products, and then to classify samples. From the chemometric evaluation of element concentrations, the first group contains tea bag samples and the second group contains the berry, juice and leaf samples.

Acknowledgements. This research was supported by grant number 172047 from the Ministry of Education, Science and Technological Development of Republic of Serbia. The authors are grateful for the financial support provided by this Ministry.

\section{References}

[1] Potter D., Eriksson T., Evans R.C., Oh S., Smedmark J.E.E., Morgan D.R., Kerr M., Robertson K.R., Arsenault M., Dickinson T.A., Campbell C.S., Phylogeny and classification of Rosaceae, Pl. Syst. Evol. 266 (2007) 5-43.
[2] Lehmann H., Die aroniabeere und ihre verarbeitung, Flüssiges. Obst. 57 (1990) 748-752.

[3] Olas B., Wachowicz B., Nowak P., Kedzierska M.A., Tomczak A., Stochmal A., Oleszek W., Jeziorski A., Piekarski J., Studies on antioxidant properties of polyphenol-rich extract from berries of Aronia melanocarpa in blood platelets, J. Physiol. Pharmacol. 59 (2008) 823-835.

[4] Kane M.E., Dehgan B., Sheehan T.J., In vitro propagation of Florida native plants: Aronia arbutifolia, P. Fl. St. Hortic. Soc. 104 (1992) 287-290.

[5] Kulling S.E., Rawel H.M., Chokeberry (Aronia melanocarpa)A review on the characteristic components and potential health effects, Planta Med. 74 (2008) 1625-1634.

[6] Razungles A., Oszmianski J., Sapis J.C., Determination of carotenoids in fruits of Rosa sp. (Rosa Canina and Rosa Rugosa) and of chokeberry (Aronia Melanocarpa), J. Food Sci. 54 (1989) 774-775.

[7] Stralsjo L., Ahlin H., Witthoft C.M., Jastrebova J., Folate determination in Swedish berries by radioprotein-binding assay (RPBA) and high performance liquid chromatography (HPLC), Eur. Food Res. Technol. 216 (2003) 264-269.

[8] Weinges K., Schick H., Schilling G., Irngartinger H., Oeser T., Composition of an anthocyan concentrate from Aronia melanocarpa elliot-X-ray analysis of tetraacetyl parasorboside, Eur. J. Org. Chem. 1 (1998) 189-192.

[9] Tanaka T, Tanaka A., Chemical components and characteristics of blackchokeberry, J. Jpn. Soc. Food. Sci. Technol. 48 (2001) 606-610.

[10] Lehmann H., Die Aroniabeere und ihre verarbeitung, Flüssiges Obst. 57 (1990) 746-752.

[11] Ognik K., Rusinek E., Sembratowicz I., Truchlinski J., Contents of heavy metals, nitrate (V), and nitrate (III) in fruits of elderberry and black chokeberry depending on harvest site and vegetation period. Rocz. Panstw. Zakl. Hig. 57 (2006) 235-41.

[12] Klaassen C.D., Casarettand Doull's Toxicology: The Basic Science of Poisons, 5th ed., McGraw-Hill, Blacklick, Ohio, U.S.A., 1995.

[13] Needleman H., Lead poisoning, Annu. Rev. Med. 55 (2004) 209-222.

[14] Hou S., Yuan L., Jin P., Ding B., Qin N., Li L., Liu X., Wu Z., Zhao G., Deng Y., A clinical study of the effects of lead poisoning on the intelligence and neurobehavioral abilities of children, Theor. Biol. Med. Modelling 10 (2013) 13.

[15] Kara D., Evaluation of trace metal concentrations in some herbs and herbal teas by principal component analysis, Food Chem. 114 (2009) 347-354.

[16] Miller J.N., Miller J.C., Statistics and chemometric for analytical chemistry, Pearson Education Limited, England, 2005.

[17] WHO, Trace elements in human nutrition and health, World Health Organization, Geneva, Switzerland, 1996.

[18] Institute of Medicine, Dietary reference intakes for water, potassium, sodium, chloride and sulfate, National Academy of Science, 2004, www.nap.edu

[19] Institute of Medicine, Dietary reference intakes for calcium, phosphorus, magnesium, vitamin D, and fluoride, National Academy of Science, 1997, www.nap.edu.

[20] Konić-Ristić A., Šavikin K., Zdunić G., Janković T., Juranić Z., Menković N., Biological activity and chemical composition of different berry juices, Food Chem. 125 (2011) 1412-1417. 
[21] Ozcan M.M., Haciseferogullari H., The strawberry (Arbutus unedo L.) fruits: chemical composition, physical properties and mineral contents, J. Food Eng. 78 (2007) 1022-1028.

[22] Radwan M.A., Salama A.K., Market basket survey for some heavy metals in Egyptian fruits and vegetables. Food Chem. Toxicol. 44 (2006) 1273-1278.

[23] Bagdatlioglu N., Nergiz C., Heavy metals in leafy vegetables and some selected fruits, J. Verbr. Lebensm. 5 (2010) 421-428.

[24] Millour S., Noël L., Kadar A., Chekri R., Vastel C., Sirot V., Leblanc J-C., Guérin T., $\mathrm{Pb}, \mathrm{Hg}, \mathrm{Cd}$, As, $\mathrm{Sb}$ and $\mathrm{Al}$ levels in foodstuffs from the 2nd French total diet study, Food Chem. 126 (2011) 1787-1799.
[25] Sarkar B., Heavy metals in the environment, Marcel Dekker, Inc., New York, U.S.A., 2002

[26] Järup L., Hazards of heavy metal contamination, Br. Med. Bull. 68 (2003) 167-182.

[27] EC, Commission of the European Communities, Commission Regulation (EC) No. 1881/2006, Regulation of setting maximum levels for certain contaminants in foodstuffs, Official Journal of European Union, L364-5/L364-24, 2006.

[28] WHO, Monograph on selected medicinal plants, Vol. 1., World Health Organization, Geneva, Switzerland, 1999.

[29] Anderson T.W., An introduction to multivariate statistical analysis, Hoboken, John Wiley and Sons, New York, U.S.A., 2003.

Cite this article as: Aleksandra N. Pavlović, Jelena M. Brcanović, Jovana N. Veljković, Snežana S. Mitić, Snežana B. Tošić, Biljana M. Kaličanin, Danijela A. Kostić, Miodrag S. Đorđević, Dragan S. Velimirović. Characterization of commercially available products of aronia according to their metal content. Fruits 70 (2015) 385-393. 